\title{
SDS-PAGE of seed proteins and SEM of seed coat surface in Caesalpinia gilliesii Wall., C. pulcherrima Sw., C. sepiaria Roxb. and Delonix regia Raf. (Leguminosae - Caesalpinioideae)
}

\author{
Maged M. Abou-El-Enain*
}

And

Mohammed H. Loutfy ${ }^{* *}$

Biological Sciences and Geology Department, Faculty of Education, Ain Shams University, Roxy (Heliopolis) P.C. 11341, Cairo, Egypt.

\begin{abstract}
Abou-El-Enain M. M. \& Loutfy M. H. 1999. SDS-PAGE of seed proteins and SEM of seed coat surface in Caesalpinia gilliesii Wall., C. pulcherrima Sw., C. sepiaria Roxb. and Delonix regia Raf. (Leguminosae Caesalpinioideae). Taeckholmia 19(1): 37-52.

SDS-PAGE of seed protein profiles, SEM of seed coat surface patterns and selected macromorphological characters were studied in the related taxa Caesalpinia gilliesii, C. pulcherrima, C. sepiaria and Delonix regia. The obtained characters were used as one set of data and analyzed using the NTSYS-pc program. The dendrogram produced showed a closer relationship between D. regia \& C. pulcherrima. Taxonomic relationships between the four taxa were discussed in the light of their morphological, anatomical, embryological and phytochemical criteria. Merging of C. pulcherrima in the genus Delonix has been suggested.

Key words: Caesalpinia - Caesalpinoidae - Electrophoresis - Leguminosae - Seed scan.
\end{abstract}

\section{Introduction}

Caesalpinia gilliesii, C. pulcherrima, C. sepiaria and Delonix regia are known ornamental and firewood plants distributed throughout subtropical and temperate regions (Mabberley, 1987\& 1997; Huang \& Huang, 1991). They belong to tribe Caesalpinieae and subfamily Caesalpinioideae of the Leguminosae (Polhill \& Vidal, 1981). The related taxa C. gilliesii, C. pulcherrima and Delonix regia have been either merged in one genus i.e. Poinciana (Bentham, 1865; Taubert, 1894; Melchior, 1964) or delimited in the two different genera Caesalpinia and Delonix (Pettigrew \& Watson, 1977; Polhill \& Vidal, 1981; Puy-DJ-du et al., 1995). Taxonomic relationship of these taxa; have attracted the attention of taxonomists not only because their classification is limited to a very few

Present address: Science Dept., Collage of Education for Teachers, P.O.14 (El-Akhdar), Wilayate IBRI,

Sultanate of Oman, P.C.516.

To whom correspondence should be addressed. 
characters (Lersten \& Curtis, 1994; Rudall et al. 1994) but also because of the unclear boundaries and the confusion in nomenclature between them (Kit et al., 1994; Shehata, 1997).

Several taxonomic studies have been carried out to discuss relationships of the Caesalpinia and Delonix either at the specific or at the generic level using different criteria. Nageshwar et al. (1984) and Prabha-Choudhary \& Choudhary (1987) analyzed the phytochemical structures among a number of species and pointed out the close relationships between $C$. pulcherrima and each of $C$. sepiaria and D. regia, respectively. Lersten and Curtis (1996) surveyed secretory structures of leaf in the Caesalpinieae and scored some differences between $C$. gilliesii, C. pulcherrima and D. regia. Shehata (1997) studied the morphological, anatomical \& embryological features in the latter three taxa and pointed out the similarity of their embryological characters and differences in some morphological and anatomical features. However, no previous studies have used the seed protein electrophoresis or seed coat surface criteria to discuss the relationships among the four taxa

Seed protein banding patterns as revealed by polyacrylamide gel electrophoresis in the presence of Sodium dodecyl sulfate (SDS-PAGE) have provided a valid source of taxonomic evidence for addressing taxonomic relationships at both the generic and specific levels (Ladizinsky \& Hymoitz, 1979; Cook, 1984; Badr, 1995). Variations in SDS-PAGE of seed protein profiles have successfully been used to differentiate between species in a number of genera, for example Vigna (Paino et al., 1993), Trifolium (Badr, 1995), Phaseolus (Schmit et al., 1996) and Lathyrus (El-Shanshoury, 1997). Similarly, scanning electron microscopy (SEM) of seed coat surface was found useful in the identification and classification of various taxa (Barthlott, 1981). A comparison of surface scan patterns of the seed coat has efficiently been used in studying species of some genera including Vigna (Kumar et al., 1984), Cassia (Ponomarino et al., 1990; Bhattacharya \& Saha, 1991), Sesbania (Seth \&Vijayaraghavan, 1991) and Vicia (Chernoff et al., 1992).

On the other hand, macromorphological characters can help in solving taxonomic problems and must not be ignored in reconstructing plant relationships and phylogeny (Werff \& Endress 1991; Donoghue \& Sanderson, 1992). Macromorphological criteria were used to reassess the relationships among various plant families and genera eg. Rohrer et al ., (1991) and Robertson et al., (1992) on the Rosaceae, Kadereit et al .,(1994) on the Papaveraceae and Sun \& Chung,(1986) ; Rohwer,(1994) on the Lauraceae .

In the present work, SDS-PAGE of seed protein patterns, SEM of seed coat surface criteria and selected macromorphological attributes were used to provide more information about the taxonomic relationships between Caesalpinia gilliesii Wall., $C$. pulcherrima Sw., C. sepiaria Roxb. and Delonix regia Raf .

\section{Materials and Methods}

Seeds of the examined taxa (Table 1) were collected from plants growing in the Botanical Garden of the Faculty of Education, Ain Shams University, where voucher specimens are kept at the Department of Biological Sciences and Geology. To extract seed proteins, hree replicas of $0.5 \mathrm{~g}$ of mature seeds were mixed; each with an equal weight of pure, clean, sterile fine sand and powdered using a mortar and pestle and homogenized with 0.2 $\mathrm{M}$ Tris- $\mathrm{HCl}$ buffer, $\mathrm{pH}=8$ for $1 \mathrm{~h}$ at $4{ }^{\circ} \mathrm{C}$. The extract was centrifuged at $12000 \mathrm{rpm}$ for 10 min. The supernatant (protein extract) was transferred to new tubes and immediately used 
Table 1: The taxa studied, source of their seeds, their country of origin, habit, leaf duration, flowering time \& present distribution in Egypt.

\begin{tabular}{|c|c|c|c|c|}
\hline Taxa studied & Source of seeds & Country of origin & Habit & $\begin{array}{l}\text { Leaf } \\
\text { duration }\end{array}$ \\
\hline $\begin{array}{l}\text { Caesalpinia gilliesii (Wall.) D. } \\
\text { Dietr } \\
=\text { Poinciana gilliesii Hook } \\
=\text { Erythrostemon gilliesii Link, } \\
\text { Klotzsch \& Otto. English } \\
\text { name : Bird of paradise, } \\
\text { paradise poinciana, peacock } \\
\text { flower, }\end{array}$ & $\begin{array}{l}\text { BGFE } \\
\text { The live } \\
\text { specimens } \\
\text { introduced in } \\
1986 \text { from the } \\
\text { Botanical } \\
\text { Garden. Fac. of } \\
\text { Science. Alex. } \\
\text { Univ. }\end{array}$ & $\begin{array}{c}\text { Argentina, Chile } \\
\text { \& Uruguay } \\
\text { (4) (1) (3) (2) }\end{array}$ & $\begin{array}{l}\text { Straggling } \\
\text { Unarmed } \\
\text { shrub } \\
\text { - (1) (3) }\end{array}$ & $\begin{array}{l}\text { Half deciduous } \\
\text { or deciduous } \\
\text { depending on } \\
\text { the locality }\end{array}$ \\
\hline $\begin{array}{l}\text { Caesalpinia pulcherrima (L.) } \\
\text { Swartz. } \\
\text { =Poinciana pulcherrima L. } \\
\text { English name: Barbados pride, } \\
\text { Barbados flower fence, Dwarf } \\
\text { poinciana, peacock flower. } \\
\text { (1) (3) (2) }\end{array}$ & $\begin{array}{l}\text { BGFE } \\
\text { The live } \\
\text { specimens } \\
\text { introduced in } \\
\text { BGFE } 1987 \\
\text { from the } \\
\text { Gardens of } \\
\text { Commonwe- } \\
\text { alth Cemeteries. } \\
\text { Heliopolis } \\
\text { Cairo. }\end{array}$ & $\begin{array}{l}\text { Unknown, } \\
\text { widely cultivated } \\
\text { in the tropics } \\
\text { (1) (3) (2) (6) }\end{array}$ & $\begin{array}{c}\text { Slightly } \\
\text { armed shrub } \\
\text { - (1) (3) }\end{array}$ & Half deciduous \\
\hline $\begin{array}{l}\text { Caesalpinia sepiaria } \text { Roxb }=\text {. } \\
\text { C. decapetala (Roth) Alston. } \\
\text { English name: Mysore Thorn. } \\
\text { (3) }\end{array}$ & $\begin{array}{l}\text { BGFE } \\
\text { The live } \\
\text { specimens } \\
\text { introduced in } \\
\text { BGFE } 1996 \\
\text { from Urman } \\
\text { garden. }\end{array}$ & $\begin{array}{l}\text { India } \\
\text { (3) (2) }\end{array}$ & $\begin{array}{c}\text { Scrambling } \\
\text { heavily armed } \\
\text { shrub } \\
\text { (3) }\end{array}$ & Half deciduous \\
\hline $\begin{array}{l}\text { Delonix regia } \text { (Hook). Raf = } \\
\text { Poinciana regia Bojer. } \\
\text { English name: Flame tree, } \\
\text { Flamboyant, Royal poinciana, } \\
\text { peacock flower. } \\
\text { (1) (3) (6) (2) }\end{array}$ & $\begin{array}{l}\text { BGFE } \\
\text { The live } \\
\text { specimens } \\
\text { introduced in } \\
\text { BGFE } 1982 \\
\text { from Zohariya } \\
\text { Garden. }\end{array}$ & $\begin{array}{l}\text { Madagascar } \\
\text { (5) (1) (6) (3) (2) }\end{array}$ & $\begin{array}{l}\text { Unarmed tree } \\
\text { with a broad } \\
\text { spreading } \\
\text { crown } \\
\text { (1) (6) }\end{array}$ & deciduous \\
\hline
\end{tabular}

(1) Bailey (1949)

(2) Mabberley (1997)

(3) Bailey \& Bailey (1976)

(4) Mondadori (1982)

(5) El-Hadidi \& Boulos (1988)

(6) Wyman (1977)

BGFE Botanical Garden of Faculty of Education

* Herbarium of Department of Flora \& Phytotaxonomy researches

- Herbarium of Cairo Univ. Fac. of Science. Bot. Department 
Table 1: Continued

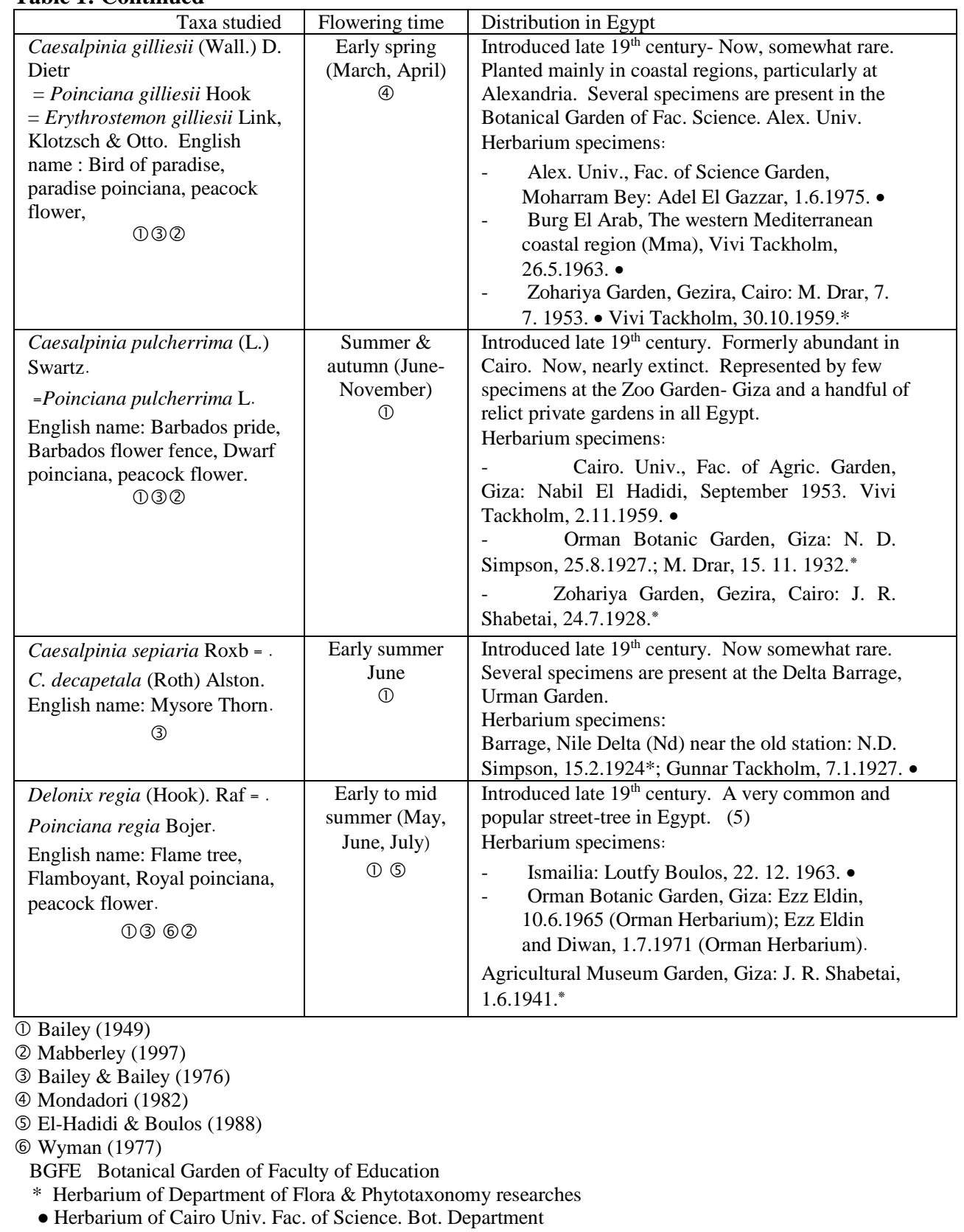


for electrophoresis or kept at $-20{ }^{\circ} \mathrm{C}$. For electrophoresis, $40 \mu \mathrm{l}$ of the extract were mixed with an equal volume of a sample buffer $(0.125 \mathrm{M}$ Tris- $\mathrm{HCl}, \mathrm{pH} 6.8,2 \%$ SDS, $10 \%$ sucrose, $0.5 \% \quad \beta$-mercaptoethanol and $0.1 \%$ bromophenol blue as a tracking dye), denatured by boiling for $5 \mathrm{~min}$ in a water bath and cooled. Then, $20 \mu \mathrm{l}$ of this mixture were loaded in $12.6 \%$ slab gel, which was prepared as described by Lammeli (1970). Electrophoresis was carried out in Tris-Glycine buffer $(\mathrm{pH}=8.3)$ at $4{ }^{\circ} \mathrm{C}$ and 125 volt for $2 \mathrm{~h}$ using a Pharmacia low-molecular weight protein mixture as standard. Gel was then stained in $0.1 \%$ Comassie Brilliant Blue R-250 for $1 \mathrm{~h}$, destained and photographed while wet and stored for subsequent examination. Total bands in the produced electropherogram were scored and their molecular weights were calculated using the standard protein marker (Table 2).

For the study of the seed coat surface using SEM technique, two seeds were mounted with colloidal silver on copper stubs, coated with a thin layer of gold in Polaron E 5000, the epidermal seed coat was photographed by a JEOL-T- Scanning Microscope at a magnification of 750, at the Electron Microscope Unit, Faculty of Science, Alexandria University. The terminology of Stearn (1966); Stant (1973); Barthlott (1981) and Boesewinkel \& Bouman (1984) were used to describe the seed coat characteristics (Table 2). Macromorphological characters were obtained from relevant literature (Bailey, 1949; Bean, 1950; Bailey \& Bailey, 1976; Wyman, 1977; Hillier, 1981; Mondadori, 1982; Mabberley, 1987; El Hadidi \& Boulos, 1988; Ibrahim, 1996; Mabberley, 1997 and Shehata, 1997). (Table 3). 
Table 2: Summary of the SDS-PAGE of seed proteins and SEM of seed coat characters of the taxa studied and their codes used in the numerical analysis.

\begin{tabular}{|c|c|c|c|c|c|c|c|}
\hline & & Chara & & & & & \\
\hline & & & & $\begin{array}{c}(1) \\
\text { C. gilliesii }\end{array}$ & $\begin{array}{c}(2) \\
\text { C. pulcherrima }\end{array}$ & $\begin{array}{c}(3) \\
\text { C. sepiaria }\end{array}$ & $\begin{array}{c}\text { (4) } \\
\text { D. regia }\end{array}$ \\
\hline & No & MY & KD) & & SDS-PAC & cters & \\
\hline & 01 & & & 0 & 1 & 1 & 0 \\
\hline & 02 & & & 1 & 1 & 1 & 1 \\
\hline & 03 & & & 1 & 1 & 1 & 1 \\
\hline & 04 & & & 1 & 0 & 0 & 1 \\
\hline & 05 & & & 0 & 1 & 0 & 1 \\
\hline & 06 & & & 1 & 1 & 1 & 0 \\
\hline & 07 & & & 0 & 0 & 0 & 1 \\
\hline & 08 & & & 1 & 0 & 0 & 1 \\
\hline I & 09 & & & 0 & 1 & 0 & 1 \\
\hline & 10 & & & 0 & 1 & 1 & 0 \\
\hline & 11 & & & 0 & 1 & 0 & 1 \\
\hline & 12 & & & 0 & 0 & 0 & 1 \\
\hline & 13 & & & 0 & 0 & 1 & 0 \\
\hline & 14 & & & 1 & 1 & 0 & 1 \\
\hline & 15 & & & 1 & 1 & 1 & 1 \\
\hline & 16 & & & 1 & 1 & 0 & 1 \\
\hline & 17 & & & 1 & 1 & 1 & 1 \\
\hline & 18 & & & 0 & 1 & 0 & 1 \\
\hline & 19 & & & 1 & 0 & 1 & 0 \\
\hline & 20 & & & 1 & 1 & 0 & 1 \\
\hline & 21 & & & 1 & 0 & 0 & 0 \\
\hline & 22 & & & 0 & 1 & 1 & 1 \\
\hline & & Epd & Cells & & SEM- & & \\
\hline & & & $\mathrm{Ru}$. & 0 & - & - & - \\
\hline & & SH & Rp. & - & 1 & - & - \\
\hline & 23 & & $\mathrm{Rm}$. & - & - & 2 & 2 \\
\hline & 24 & $\mathbf{U N}$ & Wa. & 0 & 0 & - & 0 \\
\hline & & & Sw. & - & - & 1 & - \\
\hline II & & & Vt. & 0 & - & - & 0 \\
\hline & 25 & TH & St. & - & 1 & - & - \\
\hline & & & Th. & - & - & 2 & - \\
\hline & 26 & LV & Ra. & 1 & 1 & 1 & 1 \\
\hline & 27 & & & 1 & 0 & 0 & 0 \\
\hline & 28 & & Il. & 0 & - & - & - \\
\hline III & & SH & Sc. & - & 1 & 1 & 1 \\
\hline & 29 & PA & & 0 & 0 & 0 & 1 \\
\hline
\end{tabular}

I = Protein bands, II = Anticlinal walls, III = Periclinal walls. Epd. Cells = Epidermal cells, Il. = Ildefined , KD $=$ Kilo Dalton, $\mathrm{LV}=$ Leveling, $\mathrm{MW}=$ Molecular weight, $\mathrm{PA}=$ Papillae, $\mathrm{Ra} .=$ Raised, Rm. $=$ Reticulate monomorphic, $\mathrm{Rp} .=$ Reticulate polymorphic, $\mathrm{Ru} .=$ Ruminate, $\mathrm{Sc} .=$ Slightly concave, $\mathrm{SH}=\mathrm{Shape}, \mathrm{Sr} . \mathrm{No}=$ Serial number, $\mathrm{ST}=$ Steriation, St. $=$ Slightly thick, Sw. $=$ Slightly wavy, Th. $=$ Thick, $\mathrm{TH}=$ Thickness, UN =Undulation, Vt. = Very thick, Wa. = Wavy. 
Table 3: Data matrix of the selected macromorphological Characters of the Studied taxa and their codes in the numerical analysis .

\begin{tabular}{|c|c|c|c|c|c|}
\hline \multicolumn{2}{|c|}{ Characters } & \multirow{2}{*}{ 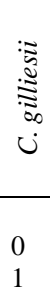 } & \multirow{2}{*}{ 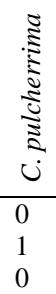 } & \multirow{2}{*}{ 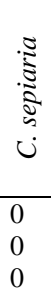 } & \multirow{2}{*}{ 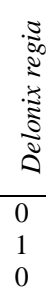 } \\
\hline Main trunk colour & $\begin{array}{l}\text { Grayish green } \\
\text { Grayish brown } \\
\text { Dark brown }\end{array}$ & & & & \\
\hline Bark texture & $\begin{array}{l}\text { Smooth glabrous } \\
\text { Rough }\end{array}$ & 0 & $\begin{array}{l}0 \\
1 \\
\end{array}$ & $\begin{array}{l}0 \\
0 \\
\end{array}$ & $\begin{array}{l}0 \\
1 \\
\end{array}$ \\
\hline Prickles on main trunk & $\begin{array}{l}\text { Absent } \\
\text { Few } \\
\text { Dense }\end{array}$ & $\begin{array}{l}0 \\
0\end{array}$ & $\begin{array}{l}0 \\
1 \\
0\end{array}$ & $\begin{array}{l}0 \\
0 \\
1 \\
\end{array}$ & $\begin{array}{l}1 \\
0 \\
0\end{array}$ \\
\hline Prickles shape & $\begin{array}{l}\text { Short, sharp-hooked } \\
\text { Slightly hooked with a globose } \\
\text { base. }\end{array}$ & 0 & $\begin{array}{l}0 \\
1\end{array}$ & $\begin{array}{l}1 \\
0\end{array}$ & $\begin{array}{l}0 \\
0\end{array}$ \\
\hline Young twigs & $\begin{array}{l}\text { Pubescent } \\
\text { Glabrous } \\
\text { Prickly } \\
\end{array}$ & $\begin{array}{l}0 \\
0 \\
\end{array}$ & $\begin{array}{l}0 \\
1 \\
0\end{array}$ & $\begin{array}{l}0 \\
0 \\
1 \\
\end{array}$ & $\begin{array}{l}0 \\
1 \\
0\end{array}$ \\
\hline No. of pinnae & $\begin{array}{l}6-10 \\
4-8 \\
6-8 \\
10-20 \\
\end{array}$ & $\begin{array}{l}0 \\
0 \\
0\end{array}$ & $\begin{array}{l}0 \\
1 \\
0 \\
0\end{array}$ & $\begin{array}{l}0 \\
0 \\
1 \\
0\end{array}$ & $\begin{array}{l}0 \\
0 \\
0 \\
1\end{array}$ \\
\hline $\begin{array}{l}\text { Pinnae arrangement on } \\
\text { rachis }\end{array}$ & $\begin{array}{l}\text { Alternate } \\
\text { Opposite }\end{array}$ & 0 & $\begin{array}{l}0 \\
1\end{array}$ & $\begin{array}{l}0 \\
1\end{array}$ & $\begin{array}{l}0 \\
1\end{array}$ \\
\hline Pinnule size & $\begin{array}{l}\text { Small }(4 \times 1.3 \mathrm{~mm}) \\
\text { Large }(10 \times 18 \mathrm{~mm}) \\
\text { Medium }(5 \times 15 \mathrm{~mm})\end{array}$ & $\begin{array}{l}0 \\
0\end{array}$ & $\begin{array}{l}0 \\
1 \\
0\end{array}$ & $\begin{array}{l}0 \\
0 \\
1\end{array}$ & $\begin{array}{l}0 \\
0 \\
1\end{array}$ \\
\hline Colour of leaves & $\begin{array}{l}\text { Dark green } \\
\text { Light green } \\
\text { Green }\end{array}$ & $\begin{array}{l}1 \\
0 \\
0 \\
\end{array}$ & $\begin{array}{l}0 \\
1 \\
0 \\
\end{array}$ & $\begin{array}{l}0 \\
1 \\
0\end{array}$ & $\begin{array}{l}0 \\
0 \\
1 \\
\end{array}$ \\
\hline Prickles on leaves & $\begin{array}{l}\text { Absent } \\
\text { On rachis } \\
\text { On rachis \&pinnae }\end{array}$ & $\begin{array}{l}1 \\
0 \\
0 \\
\end{array}$ & $\begin{array}{l}0 \\
1 \\
0 \\
\end{array}$ & $\begin{array}{l}0 \\
0 \\
1 \\
\end{array}$ & $\begin{array}{l}0 \\
0 \\
0 \\
\end{array}$ \\
\hline Infloresence type & $\begin{array}{l}\text { Racemose } \\
\text { Corymb to Racemose }\end{array}$ & $\begin{array}{l}1 \\
0\end{array}$ & $\begin{array}{l}1 \\
0\end{array}$ & $\begin{array}{l}1 \\
0\end{array}$ & $\begin{array}{l}0 \\
1 \\
\end{array}$ \\
\hline Pedicel length & $\begin{array}{l}2-2.5 \mathrm{~cm} \\
2-4 \mathrm{~cm} \\
1.5-2 \mathrm{~cm} \\
4-7 \mathrm{~cm}\end{array}$ & $\begin{array}{l}1 \\
0 \\
0 \\
0\end{array}$ & $\begin{array}{l}0 \\
1 \\
0 \\
0\end{array}$ & $\begin{array}{l}0 \\
0 \\
1 \\
0\end{array}$ & $\begin{array}{l}0 \\
0 \\
0 \\
1\end{array}$ \\
\hline Pedicel texture & $\begin{array}{l}\text { Galndular } \\
\text { Pubescent } \\
\text { Glabrous } \\
\end{array}$ & $\begin{array}{l}1 \\
0 \\
0\end{array}$ & $\begin{array}{l}0 \\
0 \\
1 \\
\end{array}$ & $\begin{array}{l}0 \\
1 \\
0\end{array}$ & $\begin{array}{l}0 \\
0 \\
1\end{array}$ \\
\hline
\end{tabular}


Table 3:Continued

\begin{tabular}{|c|c|c|c|c|c|}
\hline \multicolumn{2}{|c|}{ Characters } & \multirow{2}{*}{ 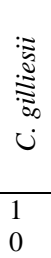 } & \multirow{2}{*}{ 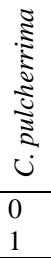 } & \multirow{2}{*}{ 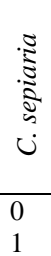 } & \multirow{2}{*}{ 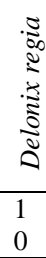 } \\
\hline Pedicel thickness & $\begin{array}{l}\text { Stout } \\
\text { Slender }\end{array}$ & & & & \\
\hline Calyx texture & $\begin{array}{l}\text { Glandular } \\
\text { Glabrous } \\
\text { Pubescent }\end{array}$ & $\begin{array}{l}1 \\
0 \\
0\end{array}$ & $\begin{array}{l}0 \\
1 \\
0\end{array}$ & $\begin{array}{l}0 \\
0 \\
1\end{array}$ & $\begin{array}{l}0 \\
1 \\
0\end{array}$ \\
\hline Sepal shape & $\begin{array}{l}\text { Imbricate unequal } \\
\text { Valvate }\end{array}$ & $\begin{array}{l}1 \\
0\end{array}$ & $\begin{array}{l}1 \\
0\end{array}$ & $\begin{array}{l}1 \\
0\end{array}$ & $\begin{array}{l}0 \\
1\end{array}$ \\
\hline Petal shape & $\begin{array}{l}\text { Thin textured, equal } \\
\text { Unequal imbricate } \\
\text { Unequal sub-orbicular }\end{array}$ & $\begin{array}{l}1 \\
0 \\
0\end{array}$ & $\begin{array}{l}0 \\
1 \\
0\end{array}$ & $\begin{array}{l}0 \\
0 \\
1\end{array}$ & $\begin{array}{l}0 \\
1 \\
0\end{array}$ \\
\hline Trichomes on floral parts & $\begin{array}{l}\text { Present } \\
\text { Absent }\end{array}$ & $\begin{array}{l}1 \\
0\end{array}$ & $\begin{array}{l}0 \\
1\end{array}$ & $\begin{array}{l}0 \\
1\end{array}$ & $\begin{array}{l}0 \\
1\end{array}$ \\
\hline Idioblasts on floral parts & $\begin{array}{l}\text { Present } \\
\text { Absent }\end{array}$ & $\begin{array}{l}0 \\
1\end{array}$ & $\begin{array}{l}1 \\
0\end{array}$ & $\begin{array}{l}0 \\
1\end{array}$ & $\begin{array}{l}0 \\
1\end{array}$ \\
\hline Stamens & $\begin{array}{l}\text { Long }(>7 \mathrm{~cm}) \\
\text { Medium }(<4-6 \mathrm{~cm})\end{array}$ & $\begin{array}{l}1 \\
0\end{array}$ & $\begin{array}{l}0 \\
1\end{array}$ & $\begin{array}{l}0 \\
1\end{array}$ & $\begin{array}{l}0 \\
1\end{array}$ \\
\hline Pod shape & $\begin{array}{l}\text { Orbicular ovate }(8 \times 2 \mathrm{~cm}) \\
\text { Obovate } 8 \times 2 \mathrm{~cm} \\
\text { Broad obovate } 7 \times 3 \mathrm{~cm} \& \text { peaked } \\
\text { Large, narrow } 40-50 \times 5 \mathrm{~cm} \& \\
\text { oblong }\end{array}$ & $\begin{array}{l}1 \\
0 \\
0 \\
0\end{array}$ & $\begin{array}{l}0 \\
1 \\
0 \\
0\end{array}$ & $\begin{array}{l}0 \\
0 \\
1 \\
0\end{array}$ & $\begin{array}{l}0 \\
0 \\
1\end{array}$ \\
\hline Pod colour & $\begin{array}{l}\text { Light brown } \\
\text { Brown } \\
\text { Dark brown }\end{array}$ & $\begin{array}{l}1 \\
0 \\
0 \\
\end{array}$ & $\begin{array}{l}0 \\
0 \\
1 \\
\end{array}$ & $\begin{array}{l}0 \\
1 \\
0 \\
\end{array}$ & $\begin{array}{l}0 \\
1 \\
0 \\
\end{array}$ \\
\hline Pod texture & $\begin{array}{l}\text { Densely pubescent } \\
\text { Glabrous }\end{array}$ & $\begin{array}{l}1 \\
0\end{array}$ & $\begin{array}{l}0 \\
1\end{array}$ & $\begin{array}{l}0 \\
1\end{array}$ & $\begin{array}{l}0 \\
1\end{array}$ \\
\hline Pod dehiscence & $\begin{array}{l}\text { Dehiscent } \\
\text { Indehiscent }\end{array}$ & $\begin{array}{l}1 \\
0\end{array}$ & $\begin{array}{l}1 \\
0\end{array}$ & $\begin{array}{l}1 \\
0\end{array}$ & $\begin{array}{l}0 \\
1 \\
\end{array}$ \\
\hline Seed shape & $\begin{array}{l}\text { Orbicular ovate } \\
\text { Obovate } \\
\text { Globose to ovate } \\
\text { Narrowly oblong }\end{array}$ & $\begin{array}{l}1 \\
0 \\
0 \\
0\end{array}$ & $\begin{array}{l}0 \\
1 \\
0 \\
0\end{array}$ & $\begin{array}{l}0 \\
0 \\
1 \\
0\end{array}$ & $\begin{array}{l}0 \\
0 \\
0 \\
1\end{array}$ \\
\hline Seed colour & $\begin{array}{l}\text { Brown with black mottling } \\
\text { Brown } \\
\text { Dark brown } \\
\text { Yellowish with brown mottling }\end{array}$ & $\begin{array}{l}1 \\
0 \\
0 \\
0\end{array}$ & $\begin{array}{l}0 \\
1 \\
0 \\
0\end{array}$ & $\begin{array}{l}0 \\
0 \\
1 \\
0\end{array}$ & $\begin{array}{l}0 \\
0 \\
0 \\
1\end{array}$ \\
\hline Seed germination & $\begin{array}{l}\text { Hypogeal } \\
\text { Epigeal }\end{array}$ & $\begin{array}{l}0 \\
1\end{array}$ & $\begin{array}{l}0 \\
1\end{array}$ & $\begin{array}{l}1 \\
0\end{array}$ & $\begin{array}{l}0 \\
1\end{array}$ \\
\hline
\end{tabular}

For data analysis, the recorded characters in each taxon i.e.SDS-PAGE protein bands, SEM features of seed surface, and the selected macromorphological characters were coded as in Tables $2 \& 3$ and used for creating the data matrix. Two phenograms, illustrating the relationships between the studied taxa were then constructed by calculating the average taxonomic distance (dissimilarity), using the NTSYS program package for IBM-pc as described by Rohlf (1993). One phenogram was based on the data of SDSPAGE and SEM seed surface, and the second, on all features combined. 


\section{Observations}

The produced banding patterns of seed protein SDS-PAGE technique of the taxa studied are shown in fig. 1-A, and the micrographs of the SEM patterns of the seed coat surface in each of the taxa studied are given in fig. 1-B. Summary of SDS-PAGE and SEM characters and their codes are given in table 2. The phenograms illustrating the relationships between the taxa studied is presented in figs. $2 \& 3$. A total number of 22 protein bands with molecular weight (MW) ranging between 99.5 Kilodalton (KD) and 15.4 KD were recorded in the electropherograms of the four taxa (Fig. 1-A \& Table 2). The highest number of bands (16) was recorded in Delonix regia, while the lowest band number (10) was observed in Caesalpinia sepiaria. Meanwhile, 12 and 15 protein bands were recorded in $C$. gilliesii and $C$. pulcherrima respectively.

Spermoderm of Caesalpinia gilliesii (Fig. 1-B \& Table 2) was characterized by having striated irregularly ruminate, very thick, wavy, raised anticlinal walls, and illdefined periclinal walls. C. Pulcherrima spermoderm differed from the above mentioned species in the following aspects:- polymorphic reticulate shape, slightly thick anticlinal walls and the smooth concave periclinal walls. C. sepiaria spermoderm is similar to that of the latter species except for the monomorphic reticulate shape and the thick slightly wavy anticlinal walls. Delonix regia spermoderm is similar to that of the above-mentioned species except for the very thick anticlinal walls and the papillate; slightly concave periclinal walls.

The phenogram constructed according to the analysis of the combined SDSPAGE and SEM characters (Fig. 2) revealed the delimiting of the studied taxa into three major phenetic lines; the first one included only $C$. gilliesii and was clustered with the second line including C. pulcherrima and Delonix regia at the dissimilarity level of 1.42. The latter two taxa were clustered together at the dissimilarity level of 1.12. The third line included only $C$. sepiaria and that was delimited as a separate phenetic line.

One the other hand, the phenogram constructed according to the analysis of all characters (SEM,SDS-PAGE and selected macromorphological characters, clearly delimited $C$. gilliesii from the other three taxa. However, $C$. sepiaria was also to a large extent, differentiated from D. regia and C. pulcherrima) (Fig .3) . 
Seed proteins and coats of some Leguminosae

Received 11 February 1999. Revision accepted 23 April 1999.

$-46-$ 


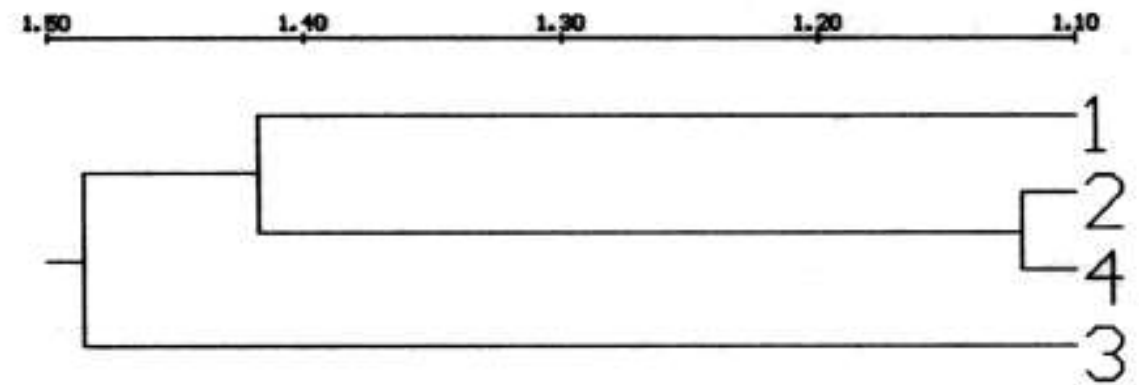

Fig. 2: The phenogram illustrating the relationships between the taxa studied (numbered as in Fig. 1) based on the variation in the combined SDS-PAGE of seed protein and SEM of seed coat surface characters.

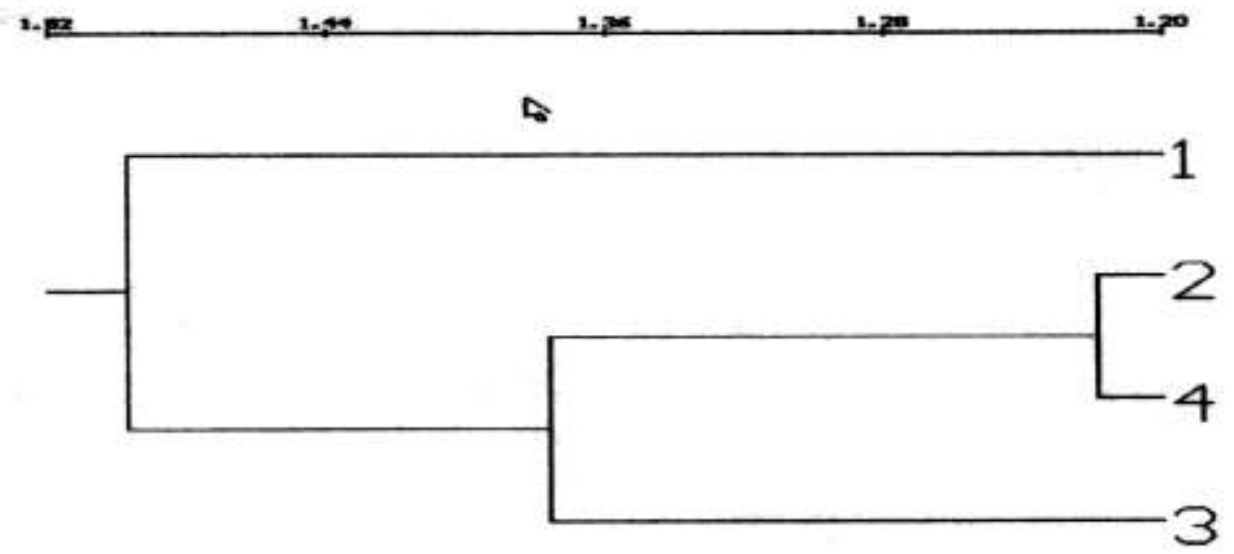

Fig. 3: The phenogram illustrating the relationships between the taxa studied (numbered as in Fig. 1) based on the variation in the combined SDS-PAGE of seed protein and SEM of seed coat surface and selected vegetative macromorphological characters. 
Seed proteins and coats of some Leguminosae

Received 11 February 1999. Revision accepted 23 April 1999.

$-48-$ 
Seed proteins and coats of some Leguminosae

\section{Discussion}

Bentham (1865), Taubert (1894) and Melchior (1964) have merged the related taxa $C$. gilliesii, C. pulcherrima and Delonix regia in the genus Poinciana as they are morphologically characterized by the tree or shrub habit, the unarmed or prickly bipinnate leaves, the terminal or axillary racemes of showy flowers, the androecium of 10 stamens with many staminodes, and the dorsifixed anthers. Pettigrew \& Watson (1977) and Polhill \& Vidal (1981) delimited these three taxa in the two related genera Caesalpinia and Delonix based mainly on the variation in habit and pod and seed characters.

The relationships based on average taxonomic distance between the studied taxa using SDS-PAGE \& SEM criteria (Fig. 2) clustered C. gilliesii, C. pulcherrima and D. regia in one major group at the dissimilarity level of 1.42. Meanwhile, C. gilliesii was distinguished from the other two taxa that clustered together showing a closer relationship between $C$. pulcherrima and D. regia. Although $C$. gilliesii was closer to the cluster of $C$. pulcherrima and $D$. regia than $C$. sepiaria, yet, the degree of dissimilarity between $C$. gilliesii and the other two taxa clearly indicate a considerable difference between them. Consequently these results do not support the grouping of C. gilliesii, C. pulcherrima and D. regia in one genus as done by Bentham, (1865); Taubert, (1894) and Melchior, (1964). Moreover, the present results contradict the grouping of $C$. gilliesii, $C$. pulcherrima in one genus and the separation of D. regia in another genus as done by Pettigrew \& Watson, (1977) and Polhill \& Vidal, (1981).

C. gilliesii, C. pulcherrima and D. regia were grouped together due to the presence of the protein bands numbered 14, $16 \& 20$ with MW of 25.2, 21.3, \& 16.5 KD, respectively, and the absence of band number 13 with a MW of $27.6 \mathrm{KD}$ in addition to the undulation of anticlinal walls as revealed by SEM of seed coat surface data. C. gilliesii was distinguished from $C$. pulcherrima and $D$. regia due to absence of the protein bands numbered 5, 9, 11, $18 \& 22$ with MW of 58.3, 38.5, 32.3, $18.6 \& 15.14 \mathrm{KD}$, respectively and the presence of the bands number $19 \& 21$ with MW of $17.8 \& 16.0$ KD respectively in addition to the ruminate shape, striated anticlinal walls and the ill-defined shape of periclinal walls .

SDS-PAGE data have revealed that $C$. pulcherrima and D. regia share 12 out of the 22 recorded protein bands. This relatively high number of common recorded bands was indicative of their common origin as observed between species of some other genera e.g. Sesbania (Saraswati et al. 1993; Badr et al., 1998) and Lathyrus (El-shanshoury 1997). SEM of seed coat data have revealed that both species are similar in the undulation, absence of striation, raised anticlinal walls, as well as the slightly concave shape of periclinal walls. Thus, the evidence obtained in the present study may indicate the possibility of merging C. pulcherrima with D. regia in the genus Delonix.

Nageshwar et al. (1984) have pointed out a close relationship between $C$. sepiaria \& $C$. pulcherrima based on the similarity in steroids \& phenol compounds. However, according to the present data it is clearly evident that these two species are quite different as they do not cluster together due to the absence of protein bands numbered 5 , $9,11,14 \& 20$ with MW of $58.3,38.5,32.3,25.2 \& 16.5 \mathrm{KD}$ respectively and the presence of bands numbered $13 \& 19$ with MW of $27.6 \& 17.8 \mathrm{KD}$ respectively in $C$. sepiaria. SEM data have also revealed that the latter species is different due to the reticulate polymorphic, undulated and slightly thick anticlinal walls. 
The phenogram constructed, utilizing all characters, Fig (3) furtherly supported the close similarity between $C$. pulcherrima and $D$. regia as the two taxa clustered at the dissimilarity level of 1.22 . Yet according to the analyzed characters, $C$. sepiaria was more close to $C$. pulcherrima and D. regia than was $C$. gilliessii.

Prabha-choudhary \& Choudhary (1987) also observed the close relationship between $C$. pulcherrima and $D$. regia based on phytochemical criteria including the similarity in phenol compounds extracted from fresh basal leaves. Shehata (1997) recorded a considerable number of embryological characters that are shared by $C$. pulcherrima \& D. regia including that of anther, ovule and integument. She also pointed out the similarity in a number of morphological and anatomical features in these two taxa including those of androecium, gynoecium, trichomes, leaves and stem.

Clustering of all the taxa studied at considerably high degree of dissimilarity i.e. the level of 1.5; reflects an apparent variability between each of $C$. gilliesii, C. sepiaria and the group comprising $C$. pulcherrima $\& D$. regia. SDS-PAGE data have indicated that all taxa shared only four out of the 22 recorded protein bands. These have the numbers of 2, 3, 15 \& 17 with MW of 96.5, 85.4, $23.4 \& 19.0 \mathrm{KD}$, respectively. SEM of seed coat surface data has revealed that they share only one character i.e. raised anticlinal walls. This provides further support to the possibility of merging C. pulcherrima with D. regia in the genus Delonix and retaining the other two taxa i.e. C. gilliesii, C. sepiaria as two different species of Caesalpinia.

C. gilliesii was shown to be standing apart from the other three taxa studied by some aspects:- ruminate spermoderm; smooth glabrous persistent grayish green bark; alternate pinnae arrangment on leaf rachis; dark green leaves; glandular pubescent floral parts. The geographical distrubution of this taxon is also different from the other three taxa. Its origin is in temperate regions (Argentina and Chile), while the others are centered in the tropics (Central America, India and Madagascar). In Egypt, it flowers in late winter and early spring, while the others flower in summer. Thus further research is still needed on this taxon in particular, to elucidate its relationships with the other taxa included in Caesalpinia, and other genera in the Caesalpineae .

\section{Acknowledgement}

The authors wish to express their deepest gratitude to Prof . Dr. Abdel Fattah Badr, professor of plant genetics \& head of Botany Department, Faculty of Science , Tanta University for revising the manuscript, providing help in the computer analysis \& his continuous encouragement .

\section{References}

Badr, A. 1995. Electrophoretic studies of seed proteins in relation to the chromosomal criteria and relationships of some taxa of Trifolium. Taxon 44:183-191.

Badr, A., Abou-El-Enain, M. M. and El-Shazly, H. H. 1998. Variation in seed protein electrophoretic pattern and species relationships in Sesbania. Proceedings of the 6th Egyptian conference of plant sciences, Cairo University (24-26 November 1998). Vol 3: 493-501.

Bailey, L.H. 1949. Manual of cultivated plants. Macmillan publishing Company, New York. Pp. 588-589. 
Bailey, L.H. \& Bailey, E.Z. 1976. Hortus Third . A concise Dictionary of Plants cultivated in the U.S.\& Canada. (Revised by Staff of the L.H. Bailey Hortorium). Macmillan publishing Co. New York. Pp: 196,367.

Barthlott, W. 1981. Epidermal and seed surface characters of plants: Systematic applicability and some evolutionary aspects. Nord.J.Bot. 1: 345-355.

Bean, W.J. 1950. Trees\&Shrubs Hardy in the British Isles. Vol. 1 from A-E. John Murray, London. Pp: 331-332.

Bentham, G. 1865. Leguminosae. In Genera Plantarum (Bentham, G. and Hooker, J. D., Eds.) vol. 1. London.

Bhattacharya, A \& Saha, P.K. 1991. Ultrastructure of seed coat and water uptake pattern of seed during germination in Cassia sp. Seed Sc. \& Tech., 18: 197-103.

Boesewinkel, F.D. \& Bouman, F. 1984. The Seed Structure. In Embryology of Angiosperms, B.M.Johri (Ed.). Springer-Verlag, Berlin Heidelberg, New York, Tokyo. Pp: 638- 681.

Chernoff, M.; Plitmann, U. \& Kislev, M.E. 1992. Seed characters and testa texture in species of the Vicieae, their taxonomic significance. Isr. J. Bot., 41: 167-186.

Cook, R. T. 1984: The characterization and identification of crop cultivars by electrophoresis. Electrophoresis (Japan) 5:59-72.

Donoghue,M.J. \& Sanderson, M.J. 1992. The Suitability of Molecular and Morphological Evidence in Reconstructing Plant Phylogeny . In " Molecular Systematics of Plants" Soltis,P.S.,Soltis , D.E , and Doyle J.J. Editors . Chapman and Hall .New York . Pp: 340-368.

El- Hadidi, M .N \& Boulos , L. 1988. The Street Trees Of Egypt (Revised Edition). The American Univ. In Cairo Press. p: 46.

El-Shanshoury, A. R. 1997. The use of seed proteins revealed by SDS-PAGE in taxonomy and phylogeny on some Lathyrus. Biol. Plant. 39:553-559.

Hillier, H.G. 1981. Hillier's Manual of Trees \& Shrubs (Fifth Edition) .Van Nostrand Reinhold company. New York. London . p:50.

Huang S.F. \& Huang T.C. 1991. Notes on the flora of Taiwan (12). The Caesalpinia L. (Leguminosae-Caesalpinioideae). Taiwania 36: 272-276.

Ibrahim, M.C. 1996. Taxonomic Studies On Some Taxa Of LeguminosaeCaesalpinioideae In Egypt. PH.D.Thesis. Fac. of Science, Ain Shams University .Pp: 96,106,110,170 .

Kadereit, J.W.; Blattner, F.R.; Jork, K.\& Schwarzbach, A. 1994. Phylogenetic analysis of the Papaveraceae S.I. ( incl . Fumariaceae, Hypecoaceae and Pteridophyllum) based on morphological characters. Bot. Jahrb. Syst . 116: 361-390.

Kit, G.C.; Lewis, G. P.; Sprent, J. I. \& Mickey, D. 1994. Chemotaxonomy of seed nonprotein amino acids in Caesalpinia s.l. In: Sprent, R. \& Mickey, D. (Eds.), Advances in legume systematics, Part 5, Pp 101-105. Royal Bot. Gard. , Kew.

Kumar, D.; Rangaswamy, N.S.\& Dinesh, K. 1984. SEM studies on seed surface of wild and cultivated species of Vigna Savi. Proc. Ind. Acad. Pl. Sc., 93: 35-42.

Ladizinsky, G. \& Hymowitz, T. 1979. Seed protein electrophoresis in taxonomic and evolutionary studies. Theo. App. Genet. 54:145-151.

Lammeli, U. 1970. Cleavage of structural proteins during the assembly of the head of bacteriophage T4. Nature 227: 680-685.

Lersten, N. R. \& Curtis, J. D. 1994. Leaf anatomy in Caesalpinia and Hoffmanseggia (Leguminosae: Caesalpinioideae) with emphasis on secretory structures. $\mathrm{Pl}$. Sys. Evol. 192: 231-255. 
Lersten, N. R. \& Curtis, J. D. 1996. Survey of leaf anatomy, especially secretory structures, of tribe Caesalpinieae (Leguminosae: Caesalpinioideae). Pl. Sys. Evol. 200:21-39.

Mabberley, D. J. 1987. The plant book: A portable dictionary of the higher plants. Cambridge University Press . New York.

Mabberley, D. J. 1997: The Plant Book, A portable dictionary of the vascular plants. Cambridge University Press . New York.

Melchior, H. 1964. Engler syllabus der pflanzenfamilien, vol. 2. Berlin.

Mondadori, A.; (1982): The Macdonald Encyclopedia of Flowers . Macdonald \& Co Ltd. London \& Sydney. p:44 .

Nageshwar, G.; Radhakrishniah, M. \& Narayan, L. 1984. Chemotaxonomy of Caesalpinia. Curr. Sc., 53: 813-814.

Paino, D; Urzo, M.; Pedalino, M. Grillo, S.; Rao, R.; Tucci, M.; Urzo-M.P.; Ng-NQ \& Monti, L.M. 1990. Variability in major seed proteins in different Vigna species. Cowpea genetic resources, 1: 90-110 (Niger).

Pettigrew, C. J. \& Watson, L. 1977. On the classification of Caesalpinioideae. Taxon 26:57-64.

Polhill, R. M. \&Vidal, J. E. 1981. Tribe 1. Caesalpinieae. In Polhill, R. M. \& Raven, P. H., (Eds.): Advances in legume systematics, Part 2, Pp. 81- 95. Royal Bot. Gard. , Kew.

Ponomareno, S.F.; Khrzhanovskii, Ya, V. \& Buivids, K.R. 1990. Seed structure of species in the genus Cassia (Tourn) L. Adaptat-sionnaya izmenchivost rastenii pri introduktsii, 40:162-164.

Prabha-Choudhary \& Choudhary, S. S. 1987. phytochemical relationship among some members of Caesalpiniaceae. Plant Phys. \& Biochem., 14: 220-226.

Puy-DJ- du; Phillipson, P.B., Rabevohitra, R. \& du-Puy-DJ. 1995. The genus Delonix (Leguminosae: Caesalpinioideae: Caesalpinieae) in Madagascar. Kew Bull., 50: 445-475.

Robertson, K.R., Phipps, J.B. \& Rohrer, J.R. 1992. Summary of leaves in the genera of Maloideae (Rosaceae) . Ann. Missouri Bot. Gard . 79: 81-94.

Rohlf, F. J. 1993. NTSYS-pc, Numerical taxonomy and multivariate analysis system. Exeter Software, New York.

Rohrer, J.R., Robertson, K.R. \& Phipps , J.B.; (1991): Variation In Structure Among Fruits Of Maloideae (Rosaceae) Amer. Jour. Bot . 78 (12) 1617- 1635.

Rohwer, J.G.1994. A note on the evolution of the stamens in the Laurales, with emphasis on the Lauraceae . Botanica. Acta (107): 2 , Pp: 103-110 .

Rudall, P.J.; Myers, G. \& Lewis, G. P. 1994. Floral secretory structures in Caesalpinia s. l. and related genera. In: Ferguson, I.K.\& Tucker, S., (Eds.), Advances in legume systematics, Part 6, Pp 41-52. Royal Bot. Gard., Kew.

Saraswati, R.; Matoh, T.; Sasai, T.; Phupaibul, P.; Lumpkin, T.; Kobayashi, M. \& Sekiya, J. 1993. Identification of Sesbania species from electrophoretic patterns of seed proteins. Trop. Agric. 70: 282-285.

Schmit, V.; Debouck, S. G. \& Baudoin, J. P. 1996. Biogeographical and molecular observations of Phaseolus glabellus (Fabaceae: Phaseolinae) and its taxonomic status. Taxon 45: 493-501.

Seth, N. and Vijayaraghavan, M.R. 1991. Differentiation of the seed coat in Sesbania speciosa. Proc. Ind. Acad. Pl. Sc., 100: 301-310. 
Shehata, A. A. 1997. Morphology and Embryology of Caesalpinia gilliesii, C. pulcherrima and Delonix regia (Leguminosae: Caesalpinioideae). J. Union Arab Biol., Cairo, 4: 197-217.

Stant, M. T. 1973. The role of the scanning electron microscope in plant. Kew Bull., 28: 105-115.

Stearn, W.T. 1966. Botanical Latin. Nelson, T. \& Sons Ltd. London, Edinburgh Pp: $506,507$.

Sun, B.Y.\& Chung, Y.H. 1986. Taxonomic Studies on the Lauraceae in Korea: morphology of inflorescences. Korean J. Bot. 29 (4) 329 -340.

Taubert, P. 1894. Leguminosae. In Die naturlichen pflanzenfamilien (Engler, A. and Prantel, K., Eds.) III. Leipzig.

Werff, H. \& Endress, P.K. 1991. Gamanthera ( Lauraceae ), A new genus from CostaRica.Ana . Missouri Bot. Gard. 78: 401- 408.

Wyman, D. 1977. Wyman's Gardening Encyclopedia Edition (2), Revised \& Expanded. Pp: 170, 303. Macmillan Publishing Co. Inc. New York. 